\title{
Effects of diets containing grape seed, linseed, or both on milk production traits, liver and kidney activities, and immunity of lactating dairy ewes
}

\author{
A. Nudda, ${ }^{* 1}$ F. Correddu, ${ }^{*}$ A. Marzano, ${ }^{*}$ G. Battacone, ${ }^{*}$ P. Nicolussi, $\dagger$ P. Bonelli, $\dagger$ and G. Pulina \\ *Dipartimento di Agraria, Sezione di Scienze Zootecniche, University of Sassari, Viale Italia 39, 07100 Sassari, Italy \\ †Istituto Zooprofilattico Sperimentale della Sardegna, Via Duca degli Abruzzi 8, 07100 Sassari, Italy
}

\begin{abstract}
This study aimed to evaluate the effects of the dietary inclusion of grape seed, alone or in combination with linseed, on milk production traits, immune response, and liver and kidney metabolic activity of lactating ewes. Twenty-four Sarda dairy ewes were randomly assigned to 4 dietary treatments consisting of a control diet $(\mathrm{CON})$, a diet containing $300 \mathrm{~g} / \mathrm{d}$ per head of grape seed (GS), a diet containing $220 \mathrm{~g} / \mathrm{d}$ per head of extruded linseed (LIN), and a diet containing a mix of $300 \mathrm{~g} / \mathrm{d}$ per head of grape seed and $220 \mathrm{~g} / \mathrm{d}$ per head of extruded linseed (MIX). The study lasted 10 wk, with 2 wk of adaptation period and 8 wk of experimental period. Milk yield was measured and samples were collected weekly and analyzed for fat, protein, casein, lactose, $\mathrm{pH}$, milk urea nitrogen, and somatic cell count. Blood samples were collected every 2 wk by jugular vein puncture and analyzed for hematological parameters, for albumin, alkaline phosphatase, bilirubin, creatinine, gamma glutamyltransferase, aspartate aminotransferase, alanine aminotransferase, protein, blood urea nitrogen, and for anti-albumin IgG, IL-6, and lymphocyte T-helper $\left(\mathrm{CD} 4^{+}\right)$and lymphocyte T-cytotoxic $\left(\mathrm{CD}^{+}\right)$cells. On d 0,45 , and 60 of the trial, lymphocyte response to phytohemagglutinin was determined in vivo on each animal by measuring skinfold thickness (SFT) at the site of phytohemagglutinin injection. Humoral response to chicken egg albumin was stimulated by a subcutaneous injection with albumin. Dietary treatments did not affect milk yield and composition. Milk urea nitrogen and lactose were affected by diet $\times$ period. Diets did not influence hematological, kidney, and liver parameters, except for blood urea nitrogen, which decreased in LIN and increased in MIX compared with CON and GS. Dietary treatments did not alter $\mathrm{CD} 4^{+}, \mathrm{CD}^{+}$, and $\mathrm{CD} 4^{+}$-to- $\mathrm{CD} 8^{+}$ratio. The SFT was reduced in GS and MIX and increased in LIN compared with CON. The IgG and IL-6 were affected
\end{abstract}

Received July 25, 2014.

Accepted October 27, 2014.

${ }^{1}$ Corresponding author: anudda@uniss.it by diet $\times$ period. The reduction in $\operatorname{IgG}$ on $\mathrm{d} 60$ and SFT in ewes fed GS suggests an immunomodulatory effect of this residue. The limited variation in milk and hematological and metabolic parameters suggests that GS and LIN can be included, alone or in combination, in the diet of dairy ewes without adverse effects on milk production and health status.

Key Words: sheep milk, grape seed, extruded linseed, immune system, liver and kidney metabolism

\section{INTRODUCTION}

Grape seed is a by-product resulting from the winery and distillery industry that requires costly disposal practices. This residue contains oil characterized by a high content of linoleic acid and by the presence of $\alpha$ - and $\beta$-tocotrienols and tocopherols, which exhibit strong antioxidant activity (Beveridge et al., 2005). Moreover, grape seeds are rich in polyphenolic compounds, such as proanthocyanidins, mainly composed of catechin, epicatechin, gallic acid, and polymeric and oligomeric procyanidins, which can be recovered by extraction (Monagas et al., 2003; González-Paramás et al., 2004). These polyphenols have antioxidant (Sharma et al., 2007), antiatherosclerotic (Leifert and Abeywardena, 2008), antibacterial, anticarcinogenic, and antiinflammatory actions (Vaid et al., 2011; Cedó et al., 2014; Cheah et al., 2014).

The literature available on the use of grape byproducts in ruminant diet is limited, probably because of their high fiber and lignin content (Spanghero et al., 2009) and the presence of secondary compounds (Makris et al., 2007; Spanghero et al., 2009), which may reduce the energy content and the digestibility of the diet (Baumgärtel et al., 2007). Conversely, the phenolic compounds linked to the hemicellulose and the acid-soluble lignin fractions in different feedstuffs (corn bran, barley grains, and barley bran) are active antioxidants (Ohta et al., 1994; Cruz et al., 2001; Yu et al., 2001). Recently, a couple of studies have focused on the effects of the dietary use of grape residues in dairy cows. Moate et al. (2014) found that pelleted and ensiled grape marc reduced methane emissions and decreased 
milk fat yield, whereas only ensiled grape marc reduced milk yield in Holstein-Friesian dairy cows. Santos et al. (2014) reported that grape residue silage improved milk quality by increasing antioxidant activity without influencing milk yield in Holstein dairy cows. Therefore, the release of phenolic compounds with antioxidant or antiinflammatory activity during the fermentation of grape seed in the rumen may be expected. For this reason, the use of grape by-products in the diet of ruminants could be not only an alternative for their disposal, but also potentially beneficial to milk production and the immune system.

Linseed has been largely studied in ruminant diets to enhance the PUFA in milk fat (Nudda et al., 2014). This feedstuff showed positive effects in small monogastrics, such as mice (Bhatia et al., 2006), broilers (Voljc et al., 2011), and rabbits (Trebušak et al., 2014), by reducing the level of oxidative stress and improving the antioxidant defense system. However, the few studies conducted about the effects of dietary linseed on oxidative stress and immunity in ruminants have had contradictory results. For example, in dairy cows, some experiments noted that linseed has antioxidative properties (Schogor et al., 2013), whereas others observed a proinflammatory effect (Caroprese et al., 2009). Comparing the effects of diets containing grape seed and linseed could help to elucidate their individual or combined effects on health status and production in ruminants. The aim of the current experiment was to test the effects of the dietary inclusion of grape seed, linseed, or both on milk production traits, immune response, and liver and kidney metabolic activity in lactating dairy ewes.

\section{MATERIALS AND METHODS}

\section{Animals, Design, Treatments, and Samples Collection}

Twenty-four Sarda dairy ewes in the first part of lactation $(<50$ DIM) were allocated to 4 groups (6 animals per group) balanced for milk yield, BW, DIM, and number of lactation. Each group was confined in a pen and then randomly assigned to 1 of 4 experimental diets: a control diet (CON), a diet containing $300 \mathrm{~g} / \mathrm{d}$ per head of grape seed (GS), a diet containing $220 \mathrm{~g} / \mathrm{d}$ per head of extruded linseed (LIN), and a diet containing a mix of $300 \mathrm{~g} / \mathrm{d}$ per head of grape seed and $220 \mathrm{~g} / \mathrm{d}$ per head of extruded linseed (MIX). The grape seed was obtained from different red grape varieties after winemaking and distillation processes followed by drying $(97 \% \mathrm{DM})$. Whole grape seeds were finely ground to obtain a grape seed meal before their use. The dose of $300 \mathrm{~g} / \mathrm{d}$ per head of grape seed (total phenolic con- tent: $333.3 \pm 10.1 \mathrm{mg}$ of gallic acid equivalent/100 g of DM) was used to provide $1 \mathrm{~g} / \mathrm{d}$ of total polyphenols. The dose of $220 \mathrm{~g} / \mathrm{d}$ per head of extruded linseed was used to supply $70 \mathrm{~g} / \mathrm{d}$ of fat.

The ingredients and chemical composition of the diets are given in Table 1. Sheep received a common ration consisting of beet pulp, a commercial concentrate, chopped dehydrated alfalfa, and mixed hay. In addition, the ewes were offered a mixed meal composed of corn, soybean, peas, grape seed, and linseed at varying levels depending on the dietary treatment. The different levels of corn, soybean, and peas in the mixed meal used in the study aimed to obtain isoenergetic and isonitrogenous diets. Chopped dehydrated alfalfa and mixed hay were offered to each group of 6 ewes in the pens (group feeding). All other dietary ingredients were provided to each animal by using individual feeders and their intake was monitored and measured individually.

The daily dose of commercial concentrate was provided at the 2 daily milkings (0730 and $1730 \mathrm{~h}$ ). The mixed meal was offered $2 \mathrm{~h}$ after each milking. Subsequently, beet pulp and then dehydrated alfalfa were provided. The mixed hay was provided during the night. Clean water was always available. The study lasted 10 wk, with 2 wk of adaptation and 8 wk of experiment.

Diets were formulated to meet the energy and protein requirements of the dairy ewes using the Small Ruminant Nutrition System model (Tedeschi et al., 2010). The nutritive value of the diets, estimated by the Small Ruminant Nutrition System model, and the calculated ME supplied are reported in Table 1 . The fat content in the diets was 2.0, 3.2, 5.1, and 5.8\% DM for the CON, GS, LIN, and MIX diets, respectively (Table 1).

Samples of dietary ingredients were collected once before the beginning of the experiment for DM determination and chemical analysis. Body weight was monitored at the beginning, in the middle, and at the end of the trial. On d 7, 14, 21, 28, 35, 42, 49, and 56, milk yield was recorded and milk samples were collected at the 2 daily milkings. On d 0 (before starting the experimental treatment), 15, 30, 45, and 60 of the experiment, a blood sample was taken from the jugular vein of each ewe and collected in a heparinized vacuum tube (Becton Dickinson, Plymouth, UK). Blood samples were centrifuged at $1,200 \times g$ for $15 \mathrm{~min}$ at $25^{\circ} \mathrm{C}$ to separate plasma from the corpusculate fraction.

\section{Feed and Milk Analysis}

The DM content of the feed was determined by oven-drying at $105^{\circ} \mathrm{C}$ for $24 \mathrm{~h}$. Dried feed samples were analyzed for NDF, ADF, and ADL (using the filter bag equipment; Ankom Technology Corp., Fairport, NY; Van Soest et al., 1991), ash (AOAC International, 
Table 1. Ingredients and chemical composition and ME concentration of the diets supplied to lactating ewes

\begin{tabular}{|c|c|c|c|c|}
\hline \multirow[b]{2}{*}{ Item } & \multicolumn{4}{|c|}{$\operatorname{Diet}^{1}$} \\
\hline & $\mathrm{CON}$ & GS & LIN & MIX \\
\hline \multicolumn{5}{|l|}{ Ingredient, $\mathrm{kg} / \mathrm{d}$ per head } \\
\hline \multicolumn{5}{|l|}{ Mixed meal } \\
\hline Corn & 0.15 & 0.17 & - & - \\
\hline Soybean & 0.12 & 0.24 & 0.04 & 0.16 \\
\hline Peas & 0.25 & 0.09 & 0.15 & 0.02 \\
\hline Grape seed & - & 0.30 & - & 0.30 \\
\hline Linseed & - & - & 0.22 & 0.22 \\
\hline Beet pulp & 0.40 & 0.40 & 0.40 & 0.40 \\
\hline Commercial concentrate & 0.50 & 0.50 & 0.50 & 0.50 \\
\hline Dehydrated alfalfa hay & 0.80 & 0.80 & 0.80 & 0.80 \\
\hline Mixed hay ${ }^{2}$ & 0.20 & 0.20 & 0.20 & 0.20 \\
\hline Total DM supplied & 2.20 & 2.47 & 2.11 & 2.39 \\
\hline \multicolumn{5}{|c|}{ Chemical composition, $\%$ of DM (unless otherwise noted) } \\
\hline $\mathrm{DM}(\%)$ & 90.8 & 91.6 & 91.2 & 92.0 \\
\hline $\mathrm{NDF}$ & 41.8 & 42.8 & 43.7 & 44.5 \\
\hline $\mathrm{NFC}$ & 33.4 & 28.9 & 28.5 & 24.2 \\
\hline $\mathrm{ADL}$ & 4.6 & 8.9 & 5.0 & 9.4 \\
\hline $\mathrm{CP}$ & 18.0 & 17.9 & 17.9 & 17.9 \\
\hline Ash & 7.8 & 7.4 & 8.1 & 7.6 \\
\hline Ether extract & 2.0 & 3.2 & 5.1 & 5.8 \\
\hline $\mathrm{ME}, \mathrm{Mcal} / \mathrm{kg}$ of DM & 2.25 & 2.00 & 2.36 & 2.08 \\
\hline ME supplied, Mcal/d & 4.95 & 4.94 & 4.97 & 4.97 \\
\hline
\end{tabular}

2000; method 942.05), CP (AOAC International, 2000; method 988.05), and ether extract (AOAC International, 2005; method 920.39). The NFC was calculated according to Weiss (1999) as NFC (g/kg of DM) = $100-(\mathrm{NDF}+\mathrm{CP}+$ ash + ether extract). These parameters were expressed as percentage of DM. To analyze the phenolic content in the grape seed, an aliquot of randomly collected grape seeds was powdered by a blender. The powder $(1.5 \mathrm{~g})$ was then homogenized with $50 \mathrm{~mL}$ of a $70 \%$ acetone-water mixture using an Ultra Turrax homogenizer (Ultra Turrax T25, Janke \& Kunkel KG, Staufen, Germany) at 3,000 rpm for 2 min in an ice-water bath. Then, the homogenate was centrifuged at $6,000 \times g$ for $15 \mathrm{~min}$ at $4^{\circ} \mathrm{C}$ and the supernatant was filtered through Whatman 541 filter paper (Whatman, Maidstone, UK). The concentration of phenolic compounds in the grape seed was then determined by the Folin-Ciocalteu method as described by Kim et al. (2003), with some modifications. Briefly, $0.5 \mathrm{~mL}$ of the supernatant was added to $1 \mathrm{~mL}$ of Folin-Ciocalteu phenol reagent (Sigma Chemical Co., St. Louis, MO) and $9.5 \mathrm{~mL}$ of bidistilled water in a $25-\mathrm{mL}$ volumetric flask, and shaken. After $7 \mathrm{~min}, 10 \mathrm{~mL}$ of $7.5 \%$ sodium carbonate $\left(\mathrm{Na}_{2} \mathrm{CO}_{3}\right)$ was added and the mixture diluted to volume $(25 \mathrm{~mL})$ with bidistilled water and mixed thoroughly. The mixture was then stored in the dark for $120 \mathrm{~min}$ at room temperature. The absorbance was read at $750 \mathrm{~nm}$ against a blank solution. Total phenolic content was expressed as milligrams of gallic acid equivalent per $100 \mathrm{~g}$ of DM, following a calibration curve obtained using gallic acid (Sigma Chemical Co.) as the standard.

Individual milk samples from the morning and afternoon milkings were analyzed separately for fat, protein, casein, lactose, and MUN using a Milkoscan 6000 instrument (Foss Electric, Hillerød, Denmark), for SCC using a Fossomatic 360 instrument (Foss Electric), and for $\mathrm{pH}$. The value of each parameter was calculated as weighted average of the morning and afternoon data.

\section{Blood Analysis}

A clinical chemistry system (Dimension RXL, Dade Behring, Ventura, CA) was used to to quantify albumin, alkaline phosphatase (ALP), bilirubin, creatinine, gamma-glutamyl transferase (GGT), aspartate transferase, alanine transferase, protein, and BUN in serum samples. The white blood cell count, red blood cell count, hemoglobin, hematocrit, mean corpuscular volume, mean corpuscular hemoglobin, mean corpuscular hemoglobin concentration, platelets, lymphocytes, monocytes, neutrophil granulocytes, eosinophils granulocytes, and basophiles granulocytes were determined in blood samples using an electronic particle counter (MS9; Melet Schloesing Laboratoires, Osny, France). 


\section{Immunological Determinations}

Skin Test. On d 0, 45, and 60, lymphocyte proliferation was determined in vivo in each ewe by measuring the changes in the skin-fold thickness (SFT) in response to an intradermal injection with $1 \mathrm{mg} / \mathrm{mL}$ of phytohemagglutinin (Sigma-Aldrich, Poole, UK) dissolved in $1 \mathrm{~mL}$ of sterile saline solution. At each sampling, the injection was administered into the center of a 2 -cm diameter circle marked on shaved skin on each shoulder. The SFT was measured with a caliper. The change in SFT (expressed in millimeters) was calculated as the difference between the 24-h postinjection thickness and the preinjection thickness.

Humoral Response to Chicken Egg Albumin. At the start of the experiment (d 0), $6 \mathrm{mg}$ of chicken egg albumin (OVA; Sigma-Aldrich) dissolved in $1 \mathrm{~mL}$ of sterile saline solution and $1 \mathrm{~mL}$ of incomplete Freund's adjuvant (Sigma-Aldrich) were injected subcutaneously into an inner thigh of each ewe. A subsequent injection of $6 \mathrm{mg}$ of OVA in saline solution without adjuvant was administered on d 15.

ELISA Test. The anti-OVA IgG titers in ewe plasma samples were determined by an ELISA test performed in 96-well U-bottomed microtiter plates according to Caroprese et al. (2009). In particular, wells were coated with $100 \mu \mathrm{L}$ of antigen (10 mg of OVA $/ \mathrm{mL}$ of PBS) at $4^{\circ} \mathrm{C}$ for $12 \mathrm{~h}$, washed, and incubated with $1 \%$ skim milk $(200 \mu \mathrm{L})$ at $37^{\circ} \mathrm{C}$ for $1 \mathrm{~h}$ to reduce nonspecific binding. After washing, $100 \mu \mathrm{L}$ of plasma (1:5,000 dilution in PBS) per well were added and incubated at $37^{\circ} \mathrm{C}$ for 1 $\mathrm{h}$. The extent of antibody binding was detected using a horseradish peroxidase-conjugated donkey anti-ovine IgG (Sigma-Aldrich; 1:20,000 dilution in PBS; $100 \mu \mathrm{L}$ per well). Optical density was measured at a wavelength of $450 \mathrm{~nm}$. Plasma samples were read against a standard curve obtained by scalar dilution of ovine IgG. Data were expressed as micrograms of anti-OVA IgG per $100 \mu \mathrm{L}$. Interleukin-6 in plasma was detected as reported by Caroprese et al. (2009). The IL-6 data were expressed as optical densities.

Determination of Lymphocyte T-Helper and T-Cytotoxic Cells. Plasma samples were used analyzed with flow cytometry to determine lymphocyte Thelper $\left(\mathbf{C D 4}^{+}\right)$and lymphocyte T-cytotoxic $\left(\mathbf{C D 8}^{+}\right)$ cells as reported by Bonelli et al. (2013). Cells were counted in a Neubauer hemocytometer (Hausser Scientific, Horsham, PA) and concentration was adjusted to $10^{6}$ cells $/ \mathrm{mL}$. Monoclonal antibodies were used to perform 3- and 4-color immunostaining protocols.

\section{Statistical Analysis}

Data of milk yield and composition, hematological, liver, and kidney parameters were analyzed with a mixed model using PROC MIXED of SAS version 9.2 (SAS Institute Inc., Cary, NC). The model included the fixed effects of diet, period, and the diet $\times$ period interaction, plus the random effects of ewe nested within treatment. Variables obtained from blood analysis on samples collected before the beginning of the trial (i.e., on d 0) were subjected to a one-way ANOVA with the experimental group as fixed effect. The group effect was significant only for the immunological parameters $(P<$ 0.0001 ); therefore, the value on $\mathrm{d} 0$ was included as a covariable in the final model. Means were separated using Tukey test $(P<0.05)$.

\section{RESULTS AND DISCUSSION}

During the experiment, the ewes were fed in pens, 1 per group, and received the chopped dehydrated alfalfa and the mixed hay as a group, whereas the other ingredients were provided and measured individually. This poses a limitation to the study, because it was not possible to measure the individual intake of the forages. Thus, the total DM and energy intake should be considered at a group level and, in this sense, individual sheep cannot be considered as experimental units and the experiment is an unreplicated demonstration. Group feeding of the forages was chosen to avoid the inevitable stress caused by individual confinement of lactating ewes in this long-term study (10 wk in total), whose goals were to evaluate production and immunological and hematological responses to feeds with high antioxidant activity. As individual confinement was reported to affect the immune system of sheep (Degabriele and Fell, 2001) and sheep are notoriously gregarious animals, in this experiment they were kept in groups to favor normal eating and social behaviors (Hutson, 2007).

During the trial, the feedstuffs supplied individually, including those of interest in the study (i.e., grape seed and linseed), were completely eaten by the animals of all groups. This result, along with the fact that the group intake of the dehydrated alfalfa and mixed hay was complete, suggests that the inclusion of grape seed, linseed, or both in the diet of lactating ewes did not negatively affect their DM and energy intake. The BW did not differ $(P>0.05)$ between groups $(43.2 \pm 0.7$ $\mathrm{kg}$, mean $\pm \mathrm{SD})$, and increased with period $(P<0.01)$, reaching $49.1 \pm 0.7 \mathrm{~kg}$ at the end of the trial.

\section{Milk Yield and Composition}

Milk yield and composition of the experimental groups are reported in Table 2 and Figure 1. Dietary treatments did not influence milk yield and composition $(P>0.05)$. Almost all milk parameters were influenced 
Table 2. Effect of dietary grape seed and linseed, alone or in combination, and period on chemical composition of milk in dairy ewes

\begin{tabular}{|c|c|c|c|c|c|c|c|}
\hline \multirow[b]{2}{*}{ Item } & \multicolumn{4}{|c|}{ Diet $^{1}$} & \multirow[b]{2}{*}{ SEM } & \multicolumn{2}{|c|}{$P$-value ${ }^{2}$} \\
\hline & $\mathrm{CON}$ & GS & LIN & MIX & & $\mathrm{D}$ & $\mathrm{P}$ \\
\hline \multicolumn{8}{|l|}{ Yield, $\mathrm{g} / \mathrm{d}$} \\
\hline Milk & 1,490 & 1,520 & 1,620 & 1,680 & 104 & NS & $* * *$ \\
\hline Fat & 87.2 & 93.9 & 96.8 & 100.5 & 5.82 & NS & $* * *$ \\
\hline Protein & 86.2 & 87.4 & 87.0 & 91.1 & 4.97 & NS & $* * *$ \\
\hline Casein & 67.3 & 68.7 & 68.6 & 71.6 & 3.90 & NS & $* * *$ \\
\hline Lactose & 73.6 & 76.6 & 81.9 & 84.9 & 5.57 & NS & $* * *$ \\
\hline \multicolumn{8}{|l|}{ Milk composition } \\
\hline Fat, \% & 5.95 & 6.19 & 6.05 & 6.09 & 0.216 & NS & $* * *$ \\
\hline Protein, \% & 5.85 & 5.76 & 5.45 & 5.48 & 0.149 & NS & $* * *$ \\
\hline Casein, \% & 4.57 & 4.31 & 4.30 & 4.20 & 0.244 & NS & $* * *$ \\
\hline $\mathrm{pH}$ & 6.67 & 6.66 & 6.68 & 6.66 & 0.017 & NS & $* * *$ \\
\hline Log SCC, $\times 1,000$ cell $/ \mathrm{mL}$ & 2.43 & 2.44 & 2.43 & 2.15 & 0.17 & NS & $* * *$ \\
\hline
\end{tabular}

${ }^{1} \mathrm{CON}=$ control diet, $\mathrm{GS}=$ diet containing $300 \mathrm{~g}$ of grape seed, LIN = diet containing $220 \mathrm{~g}$ of linseed, MIX $=$ diet containing $300 \mathrm{~g}$ of grape seed and $220 \mathrm{~g}$ of linseed.

${ }^{2} \mathrm{D}=$ effect of diet; P: effect of period; NS indicates $P>0.05$.

$* * * P<0.001$.

by period $(P<0.001)$. Lactose $(P<0.001)$ and MUN $(P<0.05)$ were affected by the diet $\times$ period interaction, but differences among diets did not reach the level of significance within each period (Figure 1). Grape seed in the diet of dairy ewes did not reduce yield of milk or yields of milk constituents when compared with the control diet. Similarly, Santos et al. (2014) observed no effect of the dietary inclusion of grape-residue silage on milk production and protein, fat, and lactose concentrations in dairy cows. Although milk yield did not differ significantly $(P>0.05)$ among the 4 dietary groups, numerically greater values were observed in the 2 groups fed linseed (LIN and MIX) than in CON and GS. This finding is in agreement with previous observations reported in several studies on dairy goats (Nudda et al., 2013), cows (Caroprese et al., 2010; Hurtaud et al., 2010), and ewes (Gómez-Cortés et al., 2009). In our study, the differences in ME content among diets did not correspond to numerical differences in milk yield because, as planned, ME supplied was similar among groups. In fact, the greater NFC content and the lower NDF and ADL content in the CON diet was compensated by the greater fat content of the extruded linseed in the LIN and MIX diets (Table 1). Therefore, the numerically higher values of milk yield in the 2 groups containing linseed than GS and CON may have been caused by differences in the characteristics of the nutrients, especially fat as an energy source, among the diets. In all groups, milk yield decreased with period ( $P$ $<0.05$, data not shown), following the general pattern of the lactation curve in dairy sheep (Macciotta et al., 1999).

Although MUN did not differ significantly among diets within period, the values of MUN in the animals fed LIN and, to a lesser extent, MIX showed lower values during the trial compared with the other groups (Figure 1). This finding agrees with other studies in linseed-fed dairy cows (Pezzi et al., 2007) and goats (Nudda et al., 2013). We hypothesized the ewes fed linseed may have taken advantage of the low ruminal $\mathrm{CP}$ degradability resulting from the extrusion treatment (Solanas et al., 2005) and of the high lipid content of linseed, which can decrease protein degradability. The lack of effect of grape seed alone on MUN is in contrast to the work of Santos et al. (2014), which showed a reduction in MUN content in dairy cows fed grape residue silage. Generally, the binding of polyphenols to protein reduces proteolysis in some dietary ingredients, ruminal protein breakdown, and milk urea excretion. In our study, it is possible that the dose of polyphenols supplied with the grape seed $(1 \mathrm{~g} / \mathrm{d}$ of polyphenols) was not sufficient to interfere with rumen protein degradation compared with the CON group. In addition, the highest dose of soybean used in the GS diet, to make diets isonitrogenous with the CON group, might have counterbalanced the effects of the polyphenols present in the grape seed. In fact, soybean is characterized by a high fraction of rumen degradable protein, which is positively correlated with MUN (Pulina et al., 2006).

\section{Blood Parameters}

The hematological, liver, and kidney parameters are reported in Table 3 and Figure 2. The values of most blood parameters observed in our trial were within the reference ranges of biochemical parameters in Sarda sheep (Dimauro et al., 2008). The only exception was BUN, which slightly exceeded the upper value of the 

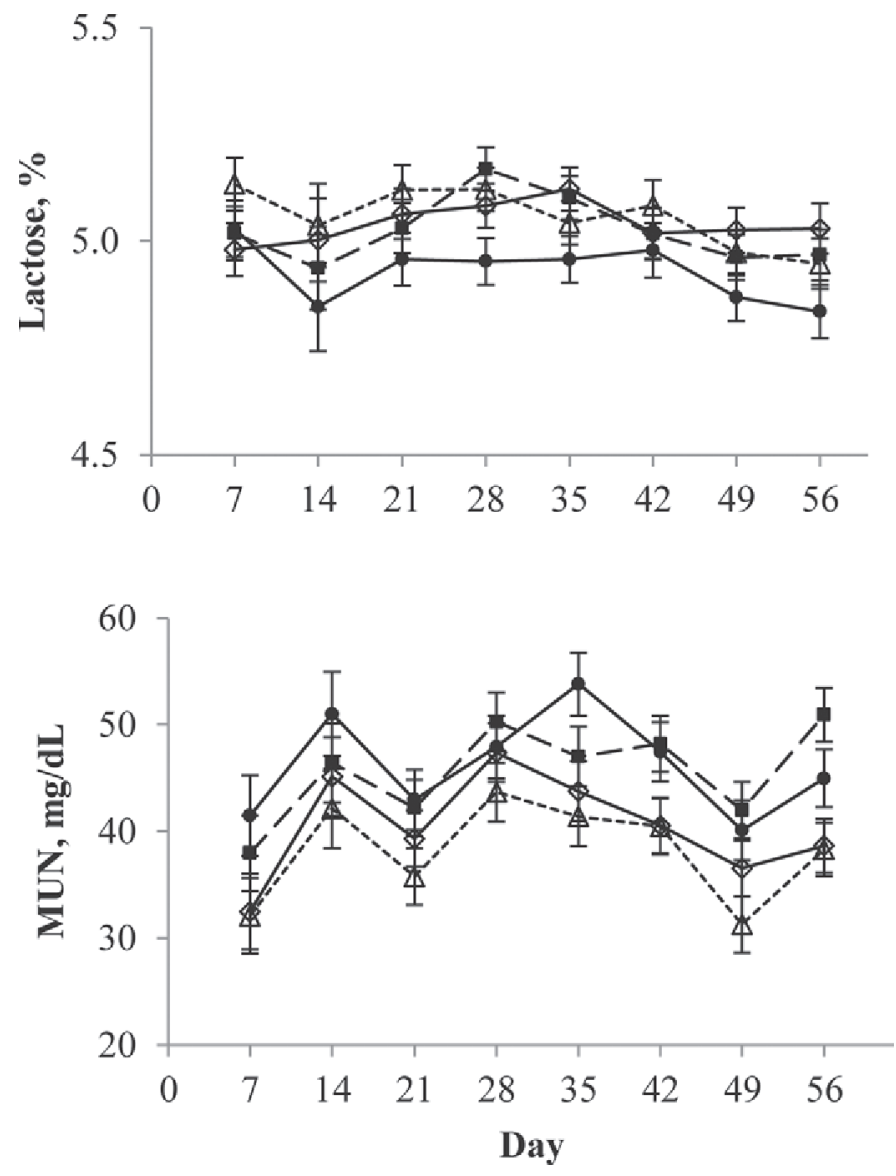

Figure 1. Temporal changes in milk lactose concentration and MUN of dairy ewes fed a control diet (solid line, $\bullet$ ), a diet containing grape seed (long-dashed line, $\mathbf{\square}$ ), a diet containing linseed (dotted line, $\Delta$ ), and a diet containing both grape seed and linseed (solid line, $\diamond$ ) Differences between dietary treatments within the same day are represented by an asterisk $(* ; P<0.05)$. Error bars represent the SEM.

reference interval (29-62 mg/dL) in the CON (63.4 mg/ $\mathrm{dL})$, GS $(63.6 \mathrm{mg} / \mathrm{dL})$, and MIX $(68.7 \mathrm{mg} / \mathrm{dL})$ groups.

Dietary treatments did not influence any of the hematological, kidney, and liver parameters measured $(P$ $>0.05)$, except for BUN, which decreased $(P<0.05)$ in LIN and increased $(P<0.05)$ in MIX compared with the CON and GS groups. Similar results were previously observed when dairy goats were fed a similar dose of extruded linseed as a source of PUFA (Nudda et al., 2013). In contrast to our results, the inclusion of grape marc in nonlactating dairy cattle reduced the concentration of BUN (Greenwood et al., 2012). However, it should be noted that the polyphenol content was lower in the grape seeds offered in the present study than in the grape marc used in that study $(45.8 \mathrm{~g} / \mathrm{kg}$ of DM). In addition, grape marc, which is constituted by grape seeds, skins, and stems after the winemaking process, contains other compounds that could also influence $\mathrm{N}$ metabolism, as hypothesized by Greenwood et al.
(2012). To our knowledge, no studies have evaluated the effects of polyphenols from grape seed extract or from grape seed by-products on liver and kidney function in ruminants. In laboratory animals, some studies showed the hepatoprotective role of grape seed extract, when liver function was experimentally altered by adding a hepatotoxic dose of acetaminophen (Ray et al., 1999) or by ligating the bile duct (Dulundu et al., 2007).

During the trial, the level of hematological, kidney, and liver parameters in blood changed with period $(P$ $<0.01$ ), except for aspartate transferase, alanine transferase, and BUN (Table 3). In general, creatinine, albumin, and protein increased, whereas ALP decreased with period (data not shown). The variation in most blood parameters with period could be due to metabolic changes related to the progress of lactation. The decrease in ALP through period (data not shown) in all experimental groups followed the same pattern of the milk yield curve, in agreement with previous observations in dairy goats (Nudda et al., 2013). A significant diet $\times$ period interaction was found only for bilirubin $(P<0.01)$ and GGT $(P<0.05)$, although no significant differences in GGT among diets were found within period (Figure 2). On d 15, bilirubin was greater in LIN and GS than in CON, with MIX being intermediate. The GGT increased in the MIX group from d 30 until the end of the trial, whereas it remained relatively constant in the other groups.

\section{Immunological Determinations}

The results of the immunological analyses are reported in Table 4 and Figure 3. The SFT was affected by dietary treatments $(P<0.05)$, being the lowest in the GS and MIX groups, the highest in the LIN group, and intermediate in CON. The SFT is used as an indirect measurement of lymphocyte proliferation, because lymphocytes are responsive to phytohemagglutinin, a mitogen that primarily stimulates $\mathrm{T}$ cell division and cytokine production (Morán et al., 2012). The reduced SFT in both groups fed grape seed suggests an inhibitory effect of this by-product on lymphocyte proliferation. Previous in vitro studies showed a similar inhibitory effect of polyphenols in human cells (Williamson et al., 2006) and in murine splenocytes (Yamanaka et al., 2012). In addition, Gessner et al. (2012) found antiinflammatory effects of phenolic compounds extracted from grape seeds and grape marc in intestinal cells under in vitro conditions. Conversely, lymphocyte-derived cytokines increased in serum samples of calves fed polyphenols extracted from pomegranate, thus showing an immune-stimulatory effect (Oliveira et al. 2010). The SFT was also affected by period, with a reduction at 
Table 3. Effect of dietary grape seed and linseed, alone or in combination, and period on blood hematological parameters and markers of liver and kidney activity of dairy ewes

\begin{tabular}{|c|c|c|c|c|c|c|c|}
\hline \multirow[b]{2}{*}{ Item $^{1}$} & \multicolumn{4}{|c|}{ Diet $^{2}$} & \multirow[b]{2}{*}{ SEM } & \multicolumn{2}{|c|}{$P$-value ${ }^{3}$} \\
\hline & $\mathrm{CON}$ & GS & LIN & MIX & & $\mathrm{D}$ & $\mathrm{P}$ \\
\hline \multicolumn{8}{|c|}{ Hematological parameter } \\
\hline WBC,$\times 10^{3}$ cells $/ \mu \mathrm{L}$ & 8.9 & 8.5 & 8.3 & 8.7 & 0.5 & NS & $* * *$ \\
\hline $\mathrm{RBC}, \times 10^{6}$ cells $/ \mu \mathrm{L}$ & 9.3 & 9.5 & 9.6 & 9.7 & 0.3 & NS & $* * *$ \\
\hline $\mathrm{HGB}, \mathrm{g} / \mathrm{dL}$ & 10.4 & 10.6 & 10.4 & 10.5 & 0.2 & NS & $* * *$ \\
\hline $\mathrm{HCT}, \%$ & 30.6 & 30.5 & 30.4 & 30.4 & 0.7 & NS & $* * *$ \\
\hline $\mathrm{MCV}, \mathrm{fL}$ & 33.1 & 32.2 & 31.7 & 31.4 & 0.8 & NS & $* * *$ \\
\hline $\mathrm{MCH}, \mathrm{pg}$ & 11.3 & 11.2 & 10.8 & 10.8 & 0.3 & NS & $* * *$ \\
\hline $\mathrm{MCHC}, \mathrm{g} / \mathrm{dL}$ & 34.1 & 34.7 & 34.1 & 34.5 & 0.3 & NS & $* * *$ \\
\hline PLT,$\times 10^{3}$ cells $/ \mu \mathrm{L}$ & 729 & 643 & 599 & 557 & 63 & NS & $* * *$ \\
\hline LYM, \% & 53.7 & 52.3 & 51.0 & 52.5 & 2.1 & NS & $* * *$ \\
\hline MONO, \% & 3.7 & 4.7 & 4.3 & 3.9 & 0.5 & NS & $* * *$ \\
\hline NEUT, $\%$ & 29.8 & 28.7 & 33.1 & 30.5 & 1.9 & NS & $* * *$ \\
\hline EOS, \% & 11.1 & 12.0 & 10.2 & 11.2 & 1.0 & NS & $* * *$ \\
\hline $\mathrm{BASO}, \%$ & 0.6 & 0.9 & 0.7 & 0.8 & 0.1 & NS & $* * *$ \\
\hline \multicolumn{8}{|l|}{ Blood metabolite } \\
\hline Albumin, $\mathrm{g} / \mathrm{dL}$ & 2.6 & 2.5 & 2.5 & 2.5 & 0.1 & NS & $* * *$ \\
\hline ALP, U/L & 108.7 & 164.4 & 128.5 & 226.8 & 36.5 & NS & $* * *$ \\
\hline Bilirubin, mg/dL & 0.19 & 0.20 & 0.23 & 0.20 & 0.0 & NS & $* *$ \\
\hline Creatinine, $\mathrm{mg} / \mathrm{dL}$ & 0.6 & 0.6 & 0.6 & 0.6 & 0.0 & NS & $* * *$ \\
\hline GGT, U/L & 77.8 & 73.0 & 78.6 & 68.7 & 8.0 & NS & $* * *$ \\
\hline $\mathrm{AST}, \mathrm{U} / \mathrm{L}$ & 142 & 140 & 119 & 165 & 15.1 & NS & NS \\
\hline ALT, U/L & 34.6 & 35.0 & 33.4 & 35.6 & 1.2 & NS & NS \\
\hline Protein, g/dL & 7.2 & 7.0 & 7.1 & 7.1 & 0.1 & NS & $* * *$ \\
\hline BUN, mg/dL & $63.4^{\mathrm{b}}$ & $63.6^{\mathrm{b}}$ & $58.0^{\mathrm{c}}$ & $68.7^{\mathrm{a}}$ & 2.1 & $* *$ & NS \\
\hline Albumin/creatinine & 4.2 & 4.2 & 1.2 & 4.1 & 0.4 & NS & NS \\
\hline Protein/creatinine & 11.8 & 12.0 & 11.7 & 11.6 & 1.2 & NS & NS \\
\hline
\end{tabular}

${ }^{\mathrm{a}-\mathrm{c}}$ Means within a row with different superscripts are different $(P<0.05)$.

${ }^{1} \mathrm{WBC}=$ white blood cell count; $\mathrm{RBC}=$ red blood cell; HGB: hemoglobin; $\mathrm{HCT}=$ hematocrit; $\mathrm{MCV}=$ mean corpuscular volume; $\mathrm{MCH}=$ mean corpuscular hemoglobin; $\mathrm{MCHC}=$ mean corpuscular hemoglobin concentration; PLT $=$ platelet; NEUT $=$ neutrophil granulocytes; LYM = lymphocytes; $\mathrm{MONO}=$ monocytes; EOS $=$ eosinophils granulocytes; BASO = basophiles granulocytes; ALP = alkaline phosphatase; GGT = gammaglutamyltransferase; AST = aspartate aminotransferase; ALT = alanine aminotransferase.

${ }^{2} \mathrm{CON}=$ control diet; $\mathrm{GS}=$ diet containing $300 \mathrm{~g}$ of grape seed; LIN = diet containing $220 \mathrm{~g}$ of linseed; MIX $=$ diet containing $300 \mathrm{~g}$ of grape seed and $220 \mathrm{~g}$ of linseed

${ }^{3} \mathrm{D}=$ effect of diet; $\mathrm{P}=$ effect of period; NS indicates $P>0.05$

$* * P<0.01 ; * * * P<0.001$.

the last sampling $(P<0.01)$, probably due to a physiological adaptation of the ewes during the trial.

A significant diet $\times$ period interaction was detected for $\operatorname{IgG}(P<0.01 ;$ Figure 3$)$. On d 45, IgG was reduced in LIN compared with the other groups, whereas on d 60 IgG was reduced in GS and MIX compared with CON and $\operatorname{LIN}(P<0.05)$. The available literature on immune functions of ruminants showed controversial

Table 4. Effect of dietary grape seed and linseed, alone or in combination, and period on immunological parameters of dairy ewes

\begin{tabular}{|c|c|c|c|c|c|c|c|}
\hline \multirow[b]{2}{*}{ Item $^{1}$} & \multicolumn{4}{|c|}{$\operatorname{Diet}^{2}$} & \multirow[b]{2}{*}{ SEM } & \multicolumn{2}{|c|}{$P$-value ${ }^{3}$} \\
\hline & $\mathrm{CON}$ & GS & LIN & MIX & & $\mathrm{D}$ & $\mathrm{P}$ \\
\hline $\mathrm{SFT}, \mathrm{mm}$ & $7.25^{\mathrm{b}}$ & $5.29^{\mathrm{c}}$ & $9.15^{\mathrm{a}}$ & $5.64^{\mathrm{c}}$ & 0.680 & * & ** \\
\hline $\mathrm{CD}^{+}, 10^{6}$ cells $/ \mathrm{mL}$ & 31.0 & 29.7 & 30.6 & 33.4 & 0.64 & NS & $* *$ \\
\hline $\mathrm{CD}^{+}, 10^{6}$ cells $/ \mathrm{mL}$ & 18.7 & 18.6 & 17.4 & 16.9 & 0.52 & NS & NS \\
\hline $\mathrm{CD} 4^{+}: \mathrm{CD}^{+}$ & 1.7 & 1.7 & 1.9 & 2.0 & 0.056 & NS & NS \\
\hline
\end{tabular}

${ }^{\mathrm{a}-\mathrm{c}}$ Means within a row with different superscripts are different $(P<0.05)$.

${ }^{1} \mathrm{SFT}=$ skinfold thickness, $\mathrm{CD} 4{ }^{+}=$lymphocyte $\mathrm{T}$-helper cells, $\mathrm{CD} 8^{+}=$lymphocyte T-cytotoxic cells.

${ }^{2} \mathrm{CON}=$ control diet; $\mathrm{GS}=$ diet containing $300 \mathrm{~g}$ of grape seed; LIN = diet containing $220 \mathrm{~g}$ of linseed; MIX

$=$ diet containing $300 \mathrm{~g}$ of grape seed and $220 \mathrm{~g}$ of linseed

${ }^{3} \mathrm{D}=$ effect of diet; $\mathrm{P}=$ effect of period; NS indicates $P>0.05$.

${ }^{*} P<0.05 ;{ }^{* *} P<0.01$. 
effects of dietary antioxidants on immunoglobulin production in ruminants (Chew, 1996; Novoa-Garrido et al., 2014). Overall, our results suggest an immunomodulatory effect of grape seed, as evidenced by the reduction in IgG titers on d 60 and in SFT. Conversely, the LIN group reduced IgG on d 45 but promoted lymphocyte proliferation. The increase in SFT due to dietary linseed is in agreement with the study of Caroprese et al. (2009) in dairy cows. Other studies reported that lymphocyte proliferation was attenuated in dairy cows fed linseed oil (Lacetera et al., 2007) or not affected in bovine peripheral blood mononuclear cells treated with $\alpha$-linolenic acid in vitro (Thanasak et al., 2005). The IL-6 concentration was influenced by a diet $\times$ period interaction $(P<0.01$; Figure 3$)$ due to an increase in titers in the MIX group on d 60 compared with the other groups.
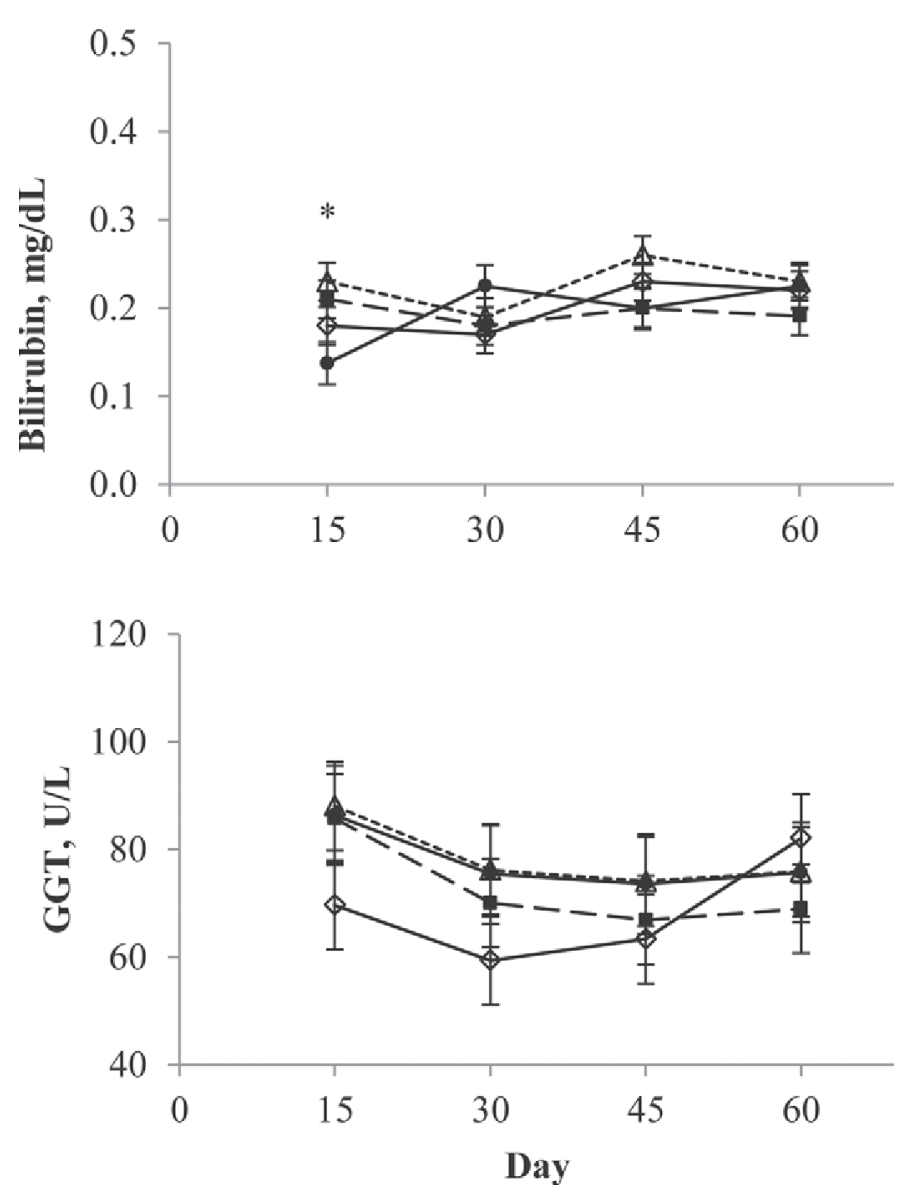

Figure 2. Temporal changes in bilirubin and gamma glutamyltransferase (GGT) in blood of dairy ewes fed a control diet (solid line, -), a diet containing grape seed (long-dashed line, $\mathbf{0}$ ), a diet containing linseed (dotted line, $\Delta$ ), and a diet containing both grape seed and linseed (solid line, $\diamond$ ). Differences between dietary treatments within the same day are represented by an asterisk (*; $P<0.05)$. Error bars represent the SEM.
The $\mathrm{CD} 4^{+}$and $\mathrm{CD} 8^{+}$cells and the $\mathrm{CD} 4^{+}$-to-CD8 ${ }^{+}$ ratio were not influenced by $\operatorname{diet}(P>0.05)$, although the $\mathrm{CD}^{+}$cells were numerically reduced in the GS group compared with the other groups. In mice, grape seed proanthocyanidins diminished regulatory $\mathrm{CD}^{+}$ cells and stimulated $\mathrm{CD} 8^{+}$cells, thus inhibiting UVBinduced immunosuppression (Vaid et al., 2011). A period effect was observed for $\mathrm{CD} 4^{+}$cells $(P<0.01)$, because of an increase $\mathrm{CD} 4^{+}$cells on $\mathrm{d} 45$ (data not shown).

It is worth noting that most of the studies concerning the effects of polyphenols on immune function and health status have been conducted in vitro or with pathological subjects. In the review by Halliwell (2008), no evidence of pro-oxidant or antioxidant effects of flavonoids in in vivo studies was found. The author of
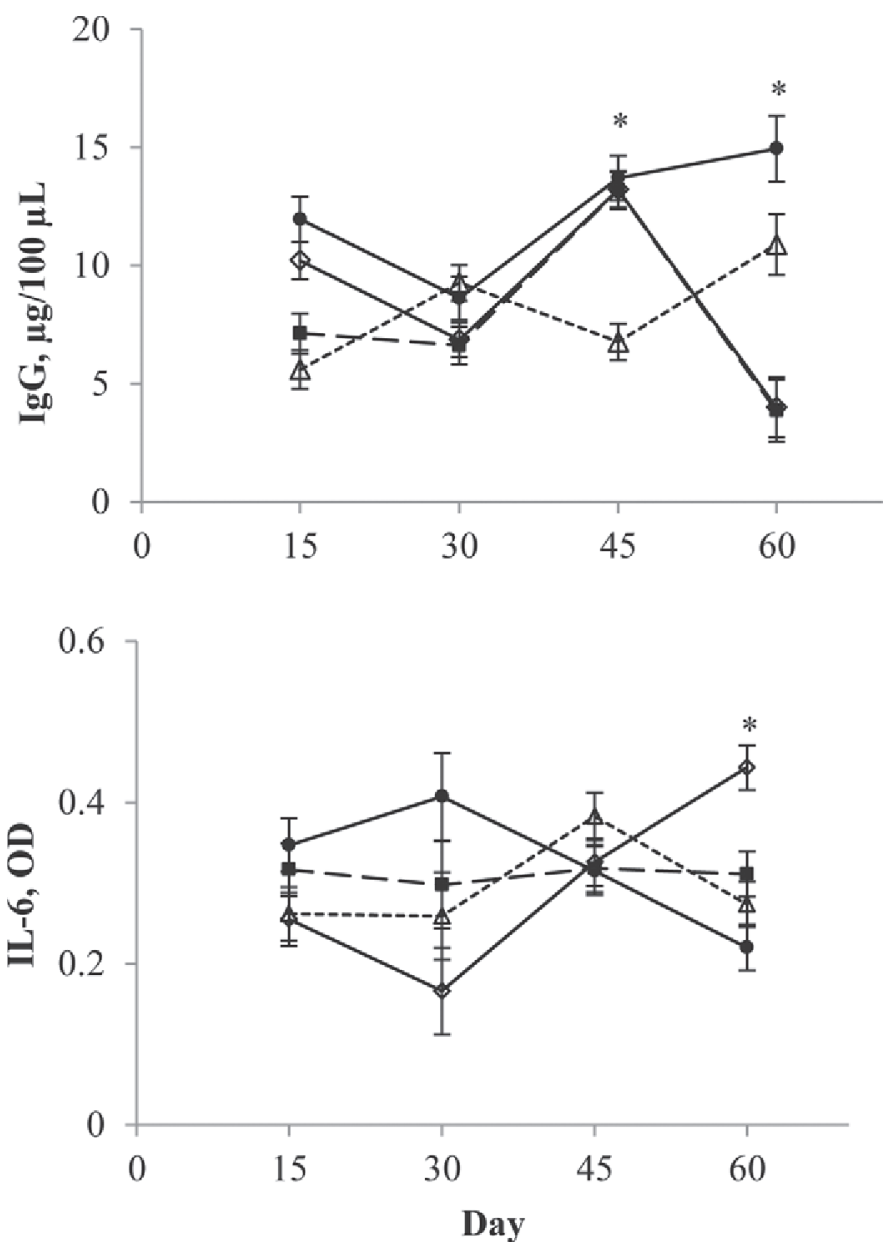

Figure 3. Temporal changes in antibody titers of IgG to chicken egg albumin (OVA) (measured by optical density, OD) and IL-6 in blood of dairy ewes fed a control diet (solid line, $\bullet$ ), a diet containing grape seed (long-dashed line, $\mathbf{\square}$ ), a diet containing linseed (dotted line, $\Delta$ ), and a diet containing both grape seed and linseed (solid line, $\diamond$ ). Differences between dietary treatments within the same day are represented by an asterisk $(* ; P<0.05)$. Error bars represent the SEM. 
the review suggested that those effects may be found in vitro only because of the high and nonphysiological levels of polyphenols normally used. Therefore, we hypothesize that grape seed dietary treatments involve a more complex physiological system than observed under in vitro conditions and that the antioxidant effects of grape seed on immune functions may not be apparent at low doses.

\section{CONCLUSIONS}

In conclusion, this study showed that grape seed, alone or with linseed, can be included in the diet of lactating ewes without influencing production traits. The reduction in some immunological parameters (i.e., IgG on d 60 and SFT) suggests that grape seed could have an immunomodulatory effect in dairy ewes. Overall, the limited variation in milk and hematological and metabolic parameters suggests that grape seed and linseed can be included, alone or in combination, in the diet of dairy ewes without adverse effects on milk production and health status.

\section{ACKNOWLEDGMENTS}

The authors thank Ana Helena Dias Francesconi, from the University of Sassari, for revising the manuscript; Antonio Fenu, Antonio Mazza, Roberto Rubat$\mathrm{tu}$, and Gesumino Spanu, also from the University of Sassari, for giving technical assistance; Azienda Ledda (Sassari, Italy) for making the farm and animals available; and Giovanni Pinna from Cargill s.r.l. (Animal Nutrition Division, Milano, Italy) for providing the feed ingredients.

\section{REFERENCES}

AOAC International. 2000. Official Methods of Analysis. 17th ed. AOAC Int., Arlington, VA.

AOAC International. 2005. Official Methods of Analysis. 18th ed. AOAC Int., Gaithersburg, MD.

Bhatia, A. L., K. Manda, S. Patni, and A. L. Sharma. 2006. Prophylactic action of linseed (Linum usitatissimum) oil against cyclophosphamide-induced oxidative stress in mouse brain. J. Med. Food 9:261-264.

Baumgärtel, T., H. Kluth, K. Epperlein, and M. Rodehutscord. 2007. A note on digestibility and energy value for sheep of different grape pomade. Small Rumin. Res. 67:302-306.

Beveridge, T. H., B. Girard, T. Kopp, and J. C. Drover. 2005. Yield and composition of grape seed oils extracted by supercritical carbon dioxide and petroleum ether: Varietal effects. J. Agric. Food Chem. 53:1799-1804.

Bonelli, P., C. Dimauro, R. Re, G. Pilo, S. Dore, A. Cannas, and P. Nicolussi. 2013. Peripheral blood and milk leukocytes subsets of lactating Sarda ewes. Ital. J. Anim. Sci. 12:208-212.

Caroprese, M., A. Marzano, G. Entrican, S. Wattegedera, M. Albenzio, and A. Sevi. 2009. Immune response of cows fed polyunsaturated fatty acids under high ambient temperatures. J. Dairy Sci. 92:2796-2803.
Caroprese, M., A. Marzano, R. Marino, G. Gliatta, A. Muscio, and A. Sevi. 2010. Linseed supplementation improves fatty acid profile of cow milk. J. Dairy Sci. 93:2580-2588.

Cedó, L., A. Castell-Auví, V. Pallarès, A. Macià, M. Blay, A. Ardévol, M. J. Motilva, and M. Pinent. 2014. Gallic acid is an active component for the anticarcinogenic action of grape seed procyanidins in pancreatic cancer cells. Nutr. Cancer 66:88-96.

Cheah, K. Y., G. S. Howarth, and S. E. Bastian. 2014. Grape seed extract dose-responsively decreases disease severity in a rat model of mucositis: Concomitantly enhancing chemotherapeutic effectiveness in colon cancer cells. PLoS ONE 9:e85184.

Chew, B. P. 1996. Importance of antioxidant vitamins in immunity and health in animals. Anim. Feed Sci. Technol. 59:103-114.

Cruz, J. M., J. M. Domínguez, H. Domínguez, and J. C. Parajó. 2001. Antioxidant and antimicrobial effects of extracts from hydrolysates of lignocellulosic materials. J. Agric. Food Chem. 49:2459-2464.

Degabriele, R., and L. R. Fell. 2001. Changes in behaviour, cortisol and lymphocyte types during isolation and group confinement of sheep. Immunol. Cell Biol. 79:583-589.

Dimauro, C. P. Bonelli, P. Nicolussi, S. P. G. Rassu, A. Cappio-Borlino, and G. Pulina. 2008. Estimating clinical chemistry reference values based on an existing data set of unselected animals. Vet. J. $178: 278-281$.

Dulundu, E., Y. Ozel, U. Topaloglu, H. Toklu, F. Ercan, N. Gedik, and G. Sener. 2007. Grape seed extract reduces oxidative stress and fibrosis in experimental biliary obstruction. J. Gastroenterol. Hepatol. 22:885-892.

Gessner, D. K., A. Fiesel, E. Most, J. Dinges, G. Wen, R. Ringseis, and K. Eder. 2012. Inhibition of the pro-inflammatory NF-jB pathway by a grape seed and grape marc meal extract in intestinal epithelial cells. J. Anim. Physiol. Anim. Nutr. (Berl.) 96:1074-1083.

Gómez-Cortés, P., A. Bach, P. Luna, M. Juárez, and M. A. de la Fuente. 2009. Effects of extruded linseed supplementation on n-3 fatty acids and conjugated linoleic acid in milk and cheese from ewes. J. Dairy Sci. 92:4122-4134.

González-Paramás, A. M. S. Esteban-Ruano, C. Santos-Buelga, S. de Pascual-Teresa, and J. C. Rivas-Gonzalo. 2004. Flavanol content and antioxidant activity in winery by products. J. Agric. Food Chem. 52:234-238.

Greenwood, S. L., G. R. Edwards, and R. Harrison. 2012. Short communication: Supplementing grape marc to cows fed a pasturebased diet as a method to alter nitrogen partitioning and excretion. J. Dairy Sci. 95:755-758.

Halliwell, B. 2008. Are polyphenols antioxidants or pro-oxidants? What do we learn from cell culture and in vivo studies? Arch. Biochem. Biophys. 476:107-112.

Hurtaud, C., F. Faucon, S. Couvreur, and J. L. Peyrault. 2010. Linear relationship between increasing amounts of extruded linseed in dairy cow diet and milk fatty acid composition and butter properties. J. Dairy Sci. 93:1429-1443.

Hutson, G. D. 2007. Behavioural principles of sheep handling. Pages 155-174 in Livestock Handling and Transport. 3rd ed. T. Grandin, ed. CAB International, Wallingford, UK.

Kim, D. O., O. K. Chun, Y. J. Kim, H. Y. Moon, and C. Y. Lee. 2003. Quantification of polyphenolics and their antioxidant capacity in fresh plums. J. Agric. Food Chem. 51:6509-6515.

Lacetera, N., D. Scalia, B. Ronchi, D. G. Mashek, U. Bernabucci, and R. R. Grummer. 2007. Effects of intravenous triacylglycerol emulsions on lymphocyte responses to mitogens in fasted dairy cows undergoing intense lipomobilization. J. Dairy Res. 74:323-328.

Leifert, W. R., and M. Y. Abeywardena. 2008. Cardioprotective actions of grape polyphenols. Nutr. Res. 28:729-737.

Macciotta, N. P.. A. Cappio-Borlino, and G. Pulina. 1999. Analysis of environmental effects on test day milk yields of Sarda dairy ewes. J. Dairy Sci. 82:2212-2217.

Makris, D. P., G. Boskou, and N. K. Andrikopoulos. 2007. Polyphenolic content and in vitro antioxidant characteristics of wine industry and other agri-food solid waste extracts. J. Food Compos. Anal. $20: 125-132$.

Moate, P. J., S. R. O. Williams, V. A. Torok, M. C. Hannah, B. E. Ribaux, M. H. Tavendale, R. J. Eckard, J. L. Jacobs, M. J. Auld- 
ist, and W. J. Wales. 2014. Grape marc reduces methane emissions when fed to dairy cows. J. Dairy Sci. 97:5073-5087.

Monagas, M., C. Gómez-Cordovés, B. Bartolomé, O. Laureano, and J. M. Ricardo da Silva. 2003. Monomeric, oligomeric, and polymeric flavan-3-ol composition of wines and grapes from Vitis vinifera $\mathrm{L}$. Cv. Graciano, Tempranillo, and Cabernet Sauvignon. J. Agric. Food Chem. 51:6475-6481.

Morán, L., S. Andrés, R. Bodas, J. Benavides, N. Prieto, V. Pérez, and F. J. Giráldez. 2012. Antioxidants included in the diet of fattening lambs: Effects on immune response, stress, welfare and distal gut microbiota. Anim. Feed Sci. Technol. 173:177-185.

Novoa-Garrido, M., L. Aanensen, V. Lind, H. J. S. Larsen, S. K. Jensen, E. Govasmark, and H. Steinshamn. 2014. Immunological effects of feeding macroalgae and various vitamin E supplements in Norwegian white sheep-ewes and their offspring. Livest. Sci. 167:126-136.

Nudda, A., G. Battacone, A. S. Atzori, C. Dimauro, S. P. G. Rassu, P. Nicolussi, P. Bonelli, and G. Pulina. 2013. Effect of extruded linseed supplementation on blood metabolic profile and milk performance of Saanen goats. Animal 7:1464-1471.

Nudda, A., G. Battacone, O. Boaventura Neto, A. Cannas, A. H. D. Francesconi, A. S. Atzori, and G. Pulina. 2014. Feeding strategies to design the fatty acid profile of sheep milk and cheese. R. Bras. Zootec. 43:445-456.

Ohta, T., S. Yamasaki, Y. Egashira, and H. Sanada. 1994. Antioxidative activity of corn bran hemicellulose fragments. J. Agric. Food Chem. 42:653-656.

Oliveira, R. A., C. D. Narciso, R. S. Bisinotto, M. C. Perdomo, M. A. Ballou, M. Dreher, and J. E. P. Santos. 2010. Effects of feeding polyphenols from pomegranate extract on health, growth, nutrient digestion, and immunocompetence of calves. J. Dairy Sci. 93:4280-4291

Pezzi, P., M. Giammarco, G. Vignola, and N. Brogna. 2007. Effects of extruded linseed dietary supplementation on milk yield, milk quality and lipid metabolism of dairy cows. Ital. J. Anim. Sci. 6:333-335.

Pulina, G., A. Nudda, G. Battacone, and A. Cannas. 2006. Effects of nutrition on the contents of fat, protein, somatic cells, aromatic compounds, and undesirable substances in sheep milk. Anim. Feed Sci. Technol. 131:255-291.

Ray, S. D., M. A. Kumar, and D. Bagchi. 1999. A novel proanthocyanidin IH636 grape seed extract increases in vivo Bcl-XL expression and prevents acetaminophen-induced programmed and unprogrammed cell death in mouse liver. Arch. Biochem. Biophys. 369:42-58.

Santos, N. W., G. T. D. Santos, D. C. Silva-Kazama, P. A. Grande, P. M. Pintro, F. E. de Marchi, C. C. Jobim, and H. V. Petit. 2014 Production, composition and antioxidants in milk of dairy cows fed diets containing soybean oil and grape residue silage. Livest. Sci. 159:37-45.

Schogor, A. L., M. F. Palin, G. T. Santos, C. Benchaar, P. Lacasse, and H. V. Petit. 2013. Mammary gene expression and activity of antioxidant enzymes and oxidative indicators in the blood, milk, mammary tissue and ruminal fluid of dairy cows fed flax meal. Br. J. Nutr. 110:1743-1750.
Sharma, S. D., S. M. Meeran, and S. K. Katiyar. 2007. Dietary grape seed proanthocyanidins inhibit UVB induced oxidative stress and activation of mitogen activated protein kinases and nuclear factor$\mathrm{KB}$ signaling in in vivo SKH-1 hairless mice. Mol. Cancer Ther. 6:995-1005.

Solanas, E., C. Castrillo, J. Balcells, and J. A. Guada. 2005. In situ ruminal degradability and intestinal digestion of raw and extruded legume seeds and soya bean meal protein. J. Anim. Physiol. Anim. Nutr. (Berl.) 89:166-171.

Spanghero, M., A. Z. M. Salem, and P. H. Robinson. 2009. Chemical composition, including secondary metabolites, and rumen fermentability of seeds and pulp of Californian (USA) and Italian grape pomaces. Anim. Feed Sci. Technol. 152:243-255.

Tedeschi, L. O., A. Cannas, and D. G. Fox. 2010. A nutrition mathematical model to account for dietary supply and requirements of energy and other nutrients for domesticated small ruminants: The development and evaluation of the Small Ruminant Nutrition System. Small Rumin. Res. 89:174-184.

Thanasak, J., K. E. Mullerb, S. J. Dielemana, A. Hoekd, J. P. T. M. Noordhuizena, and V. P. M. G. Ruttend. 2005. Effects of polyunsaturated fatty acids on the proliferation of mitogen stimulated bovine peripheral blood mononuclear cells. Vet. Immunol. Immunopathol. 104:289-295.

Trebušak, T., A. Levart, J. Salobir, and T. Pirman. 2014. Effect of Ganoderma lucidum (Reishi mushroom) or Olea europaea (olive) leaves on oxidative stability of rabbit meat fortified with n-3 fatty acids. Meat Sci. 96:1275-1280.

Vaid, M., T. Singh, A. Li, N. Katiyar, S. Sharma, C. A. Elmets, H. Xu, and S. K. Katiyar. 2011. Proanthocyanidins inhibit UV-induced immunosuppression through IL-12-dependent stimulation of $\mathrm{CD} 8+$ effector T cells and inactivation of CD4+ T cells. Cancer Prev. Res. (Phila.) 4:238-247.

Van Soest, P. J., J. B. Robertson, and B. A. Lewis. 1991. Methods for dietary fiber, neutral detergent fiber, and nonstarch polysaccharides in relation to animal nutrition. J. Dairy Sci. 74:3583-3597.

Voljc, M., T. Frankic, A. Levart, M. Nemec, and J. Salobir. 2011 Evaluation of different vitamin E recommendations and bioactivity of $\alpha$-tocopherol isomers in broiler nutrition by measuring oxidative stress in vivo and the oxidative stability of meat. Poult. Sci. 90:1478-1488.

Weiss, W. P. 1999. Energy prediction equations for ruminant feeds. Pages 176-185 in Proc. of the Cornell Nutrition Conference for Feed Manufacturers, Rochester, NY. Cornell University, Ithaca, NY.

Williamson, M. P., T. G. Mc Cormick, C. L. Nance, and W. T. Shearer. 2006. Epigallocatechin gallate, the main polyphenol in green tea binds to the T-cell receptor, CD4: Potential for HIV-1 therapy. J. Allergy Clin. Immunol. 118:1369-1374.

Yamanaka, D., Y. Tamiya, M. Motoi, K.-i. Ishibashi, N. N. Miura, Y. Adachi, and N. Ohno. 2012. The effect of enzymatically polymerised polyphenols on CD4 binding and cytokine production in murine splenocytes. PLoS ONE 7:e36025.

Yu, J., T. Vasanthan, and F. Temelli. 2001. Analysis of phenolic acids in barley by high-performance liquid chromatography. J. Agric. Food Chem. 49:4352-4358. 